\title{
Harmonisasi Hukum Perdagangan Internasional Trend Lex Mercatoria
}

\author{
Oleh : Nandang Sutrisno
}

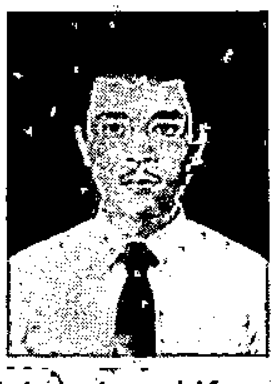

Nandang Sutrlsno, S.H., LL.M., M.Hum. adalah alumnus Fakultas Hukum UII tahun 1985. Sejak،tahun 1987 ia diangkat sebagai staf pengajar di fakultásnyạ. Sebelumnya ia bekerja pada Intèrnational Trading Company Jakarta. Memperoleh gelar Master of Laws (LL.M) dari McGill University Kanada dalam bidang Hukum Bisnis Internasional pada tahun 1994. Dalam tahun yang samaiajuga memperoleh gelar Magister Humaniora (M.Hum) dari Universitas Airlangga Surabaya. Saat ini selain sebagai Kepala Bidang Akademik Program Magister IImù Hukum, ia juga menjabat sebagai Ketua Departemen Hukum Internasional. Jabatan sebelumnyaadalah sebagai Kepala Pusat Diklat LPM-UII.

\section{Pendahuluan}

Liberalisasi perdagangan internasional, bagaimanapun argumentatifnya, telah menjadi hal yang niscaya. Adalah hal yang niscaya pula jika ia menginplikasikan semakin intensnya interaksi antar sistem atau tradisi hukum, baik antar sistem atau tradisi hukum nasional perse maupun antar sistem atau tradisi hukum dunia. Pada gilirannya fenomena tersebut mengimplikasikan kebutuhan akan harmonisasi hukum perdagangan internasional, berdasarkan asumsi bahwa liberalisāsi perdagangan akan mengalami hambatan jika aturan mainnya semata-mata diserahkan kepada masing-masing hukum nasional atau masing-masing sistem hukum.

Harmonișasi dalam konteks ini dibutuhkan untuk mengembangkan suatu framework yang konsisten dalam pengaturan perdagangan secara intemasional. Dua pendekatan terhadap harmonisasi hukum perdagangan intemasional akan digunakan dalam tulisan ini: pendekatan nasional (national approach) dan pendekatan non-nasional (nonnational_approach). ${ }^{1}$

Harmonisasi Hukum Perdagangan Internasional

Pengertian

1. Secara harfiah harmonisasi berasal dari kata harmony (Inggris) yang berarti

1). B.M. Cremades \& S.L.Plehn, "The New Lex Mercatoria and the Harmonization of the Laws of International Commercial Transactions", Boston University International Law Joürnal, Vol 2, 1994, hal. 321 
keselarasan, keserasian, kecocokan, kesesuaian, kerukunan. ${ }^{2}$ Telah banyak upaya yang dilakukan ahli hukum untuk mendeskripsikan atau mendefinisikan harmonisasi dalam pengertian hukum. Meskipun rumusan yang mereka kemukakan bervariasi, namun esensinya mengarah kepada pengertian harfiah tersebut di muka. Rene David sebagaimana dikutip oleh H. Patrick Glenn, misalnya, mendeskripsikan harmonisasi hukum. sebagai "...effectuating an understanding of differing legal concepts". ${ }^{3}$ Sedangkan MochtarKusumaatmadja mengilustrasikan bahwa harmonisasi hukum mencakup beberapa langkah: pertama, perbandingan; kedua, penyesuaian atau penyerasian; ketiga, penyamaan; dan keempat, penyatuan. ${ }^{4}$ Dengan demikian harmonisasi hukum (perdagangan internasional) menunjukkan suatu aktivitas atau upaya menyelaraskan, menyerasikan, mencocokan, menyesuaikan, menyeragamkan dan menyatukan hukum perdagangan interiasional.

\section{Harmonisasi Hukum Perdagangan Internasional}

\section{Pendekatan}

Harmonisasi hukum perdagangan intemasional tersebut dapat dilakukan melalui dua pendekatan. Pertama, pendekatan nasional (national approach) . yang bertujuan untuk membentuk hukum perdagangan hukum perdagangan nasional yang sama (uniform) atau identik antara negara yang satu dengan negara lainnya. Kedua, pendekatan non nasional (non-national approach) yang bermaksud untuk membangun rezim hukum perdagangan tunggal yang otonom (Lex Mercatoria).

\section{Pendekatan Nasional}

Dalam kerangka pendekatan nasional, harmonisasi dilakukan dengan jalan pengadopsian hukum perdagangan yang seragam olehnegara-negara. ${ }^{5}$ Ada tiga kemungkinan dalam melakukan harmonisasi menurut pendekatan ini: pertama, negara-negara, melalui perjanjian intermasional (treaty), secara timbal balik dapat mengikatkan diri pada hukum perdagangan-hukum perdagangan yang seragam; kedua, negara-negara, secara sendiri-sendiri, dapat mengadopsi "model laws" yang dirancang oleh organisasiorganisasi intemasional; dan ketiga, negaranegara secara independen dapat menguji praktek-praktek perdagangan intemasional sebagai pedoman substantí́ bersama dalam mengimplementasikan hukum perdagangan-hukum perdagangan mereka masing-masing.

\section{Perjanjian-perjanjian Internasional}

Harmonisasi hukum perdagangan internasional melalui perjanjian-perjanjian intemasional dianggap merupakan metode

2). J.M. Echols \& H. Shadily, Kamus Inggris Indonesia, PT Gramedia Pustaka Utama, Jakarta, 1993, hal 290

3). H.P. Glenn, Harmonization of Private Law Rules Between Civil and Conmon Law Jurisdictions, Makalah disampaikan pada " The XIIIth International Congress of Comparative Law", Montreal, Agustus 1990, hal. 1'

4). M. Kusumaatmadja, " Harmonisasi Hukum Negara-negara ASEAN dalam Rangka AFTA dan Harmonisasi Hukum Perdagangan Internasional pada Umumnya", Jurnal Hukum, No. 1 Vol. 1, 1994, hal. 55

5). Pendekatan nasional sangat dipengaruhi oleh teori hukum intemasional klasik bahwa hanya negera-negaralah yang menjadi subyek hukum internasional, dan hanyanegara-negaralah yang dapat membuat hukum. 
harmonisasi yang cukup efektif. Hal ini -karena ketentuan-ketentuan dalam perjanjian internasional mengikat para pihakdalam perjanjian tersebut. Di samping itu, dalam banyak negara, ratifikasi perjanjian intemasional secara otomatis mengintegrasikan seluruh ketentuan perjanjian internasional ke dalam hukum nasionalnya masing-masing. Oleh karena itu ketentuan-ketentuan hukum perjanjian internasional mengikat baik secara internasional maupun nasional, dan oleh karena itu pula keseragaman dapát dicapai dengan meyakinkan.

Namun sayang, hanya beberapa perjanjian internasional yang mengatur perdagangan intemasional saja yang telạh diratifikasi secara luas oleh negara-negara. Negara-negara dengan perbedaan tingkat perkembangan dan perbedaan kebijakan ekonomi jarang sekali mencapai kesepakatan terhadap muatan perjanjianperjanjian yang dimaksudkan.

\section{Model Laws}

Harmonisasi hukum perdagangan internasional melalui Model Laws dilakukan 'dengan cara pembuatan rancangan-rancangan hukum yang dianggap cocok unituk mengatur perdagangan internasional dan dapat diterima oleh negara-negara. Model Laws biasanya dirancang oleh kelompokkelompok kerja yang terdiri dari ahli-ahli hukum dann perdagangan dari seluruh dunia. Kelompok-kelompok kerja tersebutberada di bawah naungan lembaga-lembaga (internasional) permanen yang aktivitasaktivitasnya ditujukan kepadä perancangan Model Laws. ${ }^{6}$ Diantara lembaga-lembaga tersebut, UNCITRAL merupakan suatu lembaga yang paling berpengaruh, yang aktivitasnya selain membuat rancanganrancangan hukum juga secara umum ditujukan kepada harmonisasi hukum perdagangan internasional, khususnya dalam bidang-bidang pembayaran, jualbeli, pengangkutan dan arbitrase intemasional.

Harmonisasi hukum perdagangan intemasional melalui proses Model laws merupakan perpaduan antara harmonisasi melalui perjanjian internasional dengan tindakan unilateral mumi negara-negara. Meskipun Model Laws tidak mempunyai kekuatan mengikat sebagaimana perjanjian intemasional, tetapi melalui proses ini harmonisasi hukum juga dapat dicapai denganefektif: Hal ini karenamelalui proses ini akan dihasilkan rancangan-rancangan (draft) yang substansinya dapat diterima secara luas, yang pada gilirannya akan -menghasilkan keseragaman hukum-hukum perdagangan nasional yang mengatur perdagangan intemasional.

\section{Tindakan Unilateral Negara-negara}

Harmonisasi hukum perdagangan intemasional dapat juga dilakukan dengan. cara mengkombinasikan praktek-praktek perdagangan internasional dengan kebijakan-kebijakan domestik dalam membuat peraturan-peraturan hukum perdagangan nasionalnya masing-masing. Proses harmonisasi dilakukan olch negara masing-masing secara independen tanpa

6). Misalnya The United Nations Commission on International Trade Law (UNCITRAL). The International Institute for the Unifications of Private Law (UNIDROIT), The Haque Conference on Private Internasitonal Law dan The Council for Mutual Econoinic Assistance (CMEA) 
adanya kerjasama antara negara yang satu dengan negara yang lainnya. Dengan demikian keseragaman akan sulit dicapai, karena pengujian terhadap praktek-praktek perdagangan internasional dilakukan sendiri-sendiri yang tentu saja akan sangat bias oleh kepentingan-kepentingan negaranya masing-masing: Oleh karena itu harmonisasi dengan cara ini merupakan cara yang paling tidak efektif.

\section{Pendekatan Non-Nasional: Lex Merca- toria}

Harmonisasi hukum perdagangan internasional dengan pendekatan nonnasional dilakukan dengan cara delokalisasi atau denasionalisasi hukum dan mengembangkan Lex Mercatoria sebagai altematif.

J.G. Castel mendefinisikan Lex. Marcatoria sebagai "the customs or usages of intemational trade, or the rules of law that are common to all or most of the states engaged in intemational trade or to those that connected with the contract" ${ }^{\text {"C }}$ Christoph W.O. Stoècker, mengutip Goldman, memberikan batasan bahwa Lex Mercatoria merupakan "a set of general principles, and customary rules spontaneously referred to or elaborated in the framework of international trade, without reference to a particcular national system or laws". Sedangkan Ole Landomemberikan definisi Lex Mercatoria sebagai " Rules of law which are common to all or most of the States engaged in intemational trade or to those State that are connected with the dispute, and if not ascertainable, then the rules which appear to be the most appropriate and equitable". ${ }^{9}$ Dari definisi-definisi tersebut dapat dikatakan bahwa prinsip- prinsip dan kebiasaan-kebiasaan yang diterima secara umum dalam praktek perdagangan intemasional tanpa merujuk suatu sistem hukum nasional tertentu merupakan Lex Mercatoria. Dengan demikian Lex Mercatoria merupakan suatu sistem norma yang bersifat otonom, suatu sistem norma yang bẻrlaku di kalangan masyarakat bisnis.

Adapun elemen-elemen Lex Mercatoria meliputi: ${ }^{10}$

1. Peraturan-peraturan yang terdapat dalam perjanjian-perjanjian internasional (treaties).

2. Hukum-hukum yang seragam (Uniformed Laws) seperti the United Nations Convention on Contract for the Intemational Sales of Goods.

3. Prinsip-prinsip hukum umum yang diakui oleh bangsa-bengsa pedagang di seluruh dunia, seperti prinsippacta suint servanda.

4. Resolusi-resolusi. -

5. Rekomendasi-rekomendasi dan kodekode perilaku yang dikeluarkan oleh lembaga-lembaga international, seperti UNCITRAL dan UNIDROIT.

6. Kebiasaan-kebiasaan (the customs and usages) internasional yang berlaku

7). J.G. Castel et al., The canadian Law and Practice of International Trade with Parlicular Emphasis on Export and Import of Goods and Services, Emond Montomery Publications Limited, Toronto, 1991, hal. 115

8).C.W.O. Stoecker, "The Lec Mercatoria : To WhatExtent Does It Exist ? " Journal of International Arbitration, Vol 7, 1990, hal. 105

9). O. Lando, " The Lex Mercatoria in International Commercial Arbitration", International and Comparative Law Quarterly, Vol. 34 1985, hal 747

10). J.G. Castel et al., supra no. 7 
dalam bidang perdagangan, misalnya the Incoterms 1990, the Uniform Customs and Practices for Documentary Credits, dan juga kontrak-kontrak standar yang telah diterima secara universal.

7. Putusan-putusan arbitrase.

Norma-normá - yang dapat dikategorikạn sebagai Lex Mercatoria diantaranya adalah sebagai berikut:"

1. Suatu prinsip umum bahwa kontrakkontrak dapat dilaksanakan secara prima facie jika dilakukan menurut prinsip pacta sunt servanda.

2. Suatu kontrak harus dilaksanakan dengan itikad baik.

3. Suatu kontrak yang dilakukan dengan cara menyuap atau dengan cara-cara lain yang tidak jujur batal demi hukum, atau, paling tidak, tidak dapat dilaksanakan.

4. Jika dalam pelaksanaan suatu kontrak terdapat kesulitan-kesulitan yang tidak dapat diduga sebelumnya, dengan iktikad baik hendaknya para pihak melakukan negosiasi untuk mengatasinya, meskipun kontrak yang bersangkutan mengandung klausula "no revision".

5. Para pihak tidak diperkenankan untuk membuat syarat sepihak dalam kontrak yang membebaskan dirinya dari kewajiban.

6. Penggantian kerugian untuk pelánggaran kontrak dibatasi hanya sampai pada konsekuensi-konsekuensi pelanggaran yang dapat dilihat.

7. Penggantian kerugian sebagai akibat tidak dialihkannya barang diperhitungkan denganmemperlihatkan harga pasar dari barang yang. bersangkutan.

8. Pihak yang menderita kerugian akibat pelanggaran kontrak harus mengambil langkah-langkah yang wajar untuk menuntut ganti kerugian terhadap pihak yang melanggar kontrak.

Konsep Lex Mercatoria sudah dikenal sejak abad pertengahan, namun sampai saat ini konsep ini masih mengundang kontroversi. Di satu pihak ada yang meragukan konsep tersebut, dan di pihak lainada yangmendukungnya. Pihak pertama mempertanyakan apakah Lex Mercatoria benar-benar merupakan hukum. ${ }^{12}$ Dengan kalimat lain, apakah Lex Mercatoriabenar-benar eksis sebagai suatu sistem norma? Keraguan seperti ini didasarkan pada sulitnya aksesibilitas atau penerapan umum, lemahnya otorisasi dan konsistensi, relatifnya prediktabilitas dan ukuran keadilan.

Bagi para pendukungnya, Lex Mercatoria tidak meragukkan lagi merupakan hukum yang eksis dandiakui sebagai sistem norma yang otonom olch masyarakat bisnis dan oleh kekuasaan negara.

Melihat praktek-praktek transaksi perdagangan internasional yáng ada, eksistensi Lex Mercatoria sebenamya sudah tidak perlu diragukan lagi. Sebagai bukti bahwa ia memang benar-benar eksis dapat dilihat dari kontrak-kontrak dagang

11).T.R.H.L.J. Mustill, "The New Lex Mercatoria: The First Twenty five Years ", Arbitration Inicrnational, hal. 110-114

12). Pertanyaan serupa juga pernah dialamatkan kepada hukum intemasional publik, yang terutama berkisar pada ketiadaan alat pemaksauntuk penegakannya. 
internasional yang baik secara eksplisit maupun implisitmengandung klausula yang menunjukkan pemakaian Lex Mercatoria. Demikianjuga dalam arbitrase perdagangan internasional. ${ }^{13}$ Bahkan, dengan bermunculannya blok-blok perdagangan regional, dan dengan ditanda tangani serta diratifikasinya" The Final Act Embodying the Results of the Uruguay Round of Multilateral Trade Negotiations" oleh banyak negara, Lex Mercatoria akan semakin eksis.

Harmonisasi hukum perdagangan intemasional melalui Lex Mercatoria hemat penulis, merupákan harmonisasi yang paling ideal, karena norma-norma hukum yang dihasilkan merupakan sintesa dari berbagai macam norma yang mengaturperdagangan intemasional. Karena ia merupakan sintesa, norma-norma yang dihasilkannya pun merupakan norma-norma terbaik, dan oleh karena itu pula akan lebih mencerminkan nilai-nilai keadilan yang lebih universal, setidaknya nilai-nilai keadilan bagi yang terlibat dalam perdagangan internasional. Dengan demikian akán berarti meratakan jalan menuju harmonisasi hukum yang paling sempuma, yaitu unifikasi.

\section{Penutup}

Pendekatan mana pun yang digunakan, baik pendekatan nasional maupun non-nasional akan berarti makin memperkuat Lex Mercatoria yang diasumsikan sebagai hukum altematif yang harmonis dalam mengatur perdagangan internasional. Hal ini didasarkan pada pemikiran bahwa saat ini Lex Mercatoria. sangat tergantung pada kerjasama' antar negara. Dengan memperluas batas-batas kebebasan berkontrak, negará-negara telah meningkatkan ruang lingkup "commercial self-regulation", yang páda gilirannya membantu perkembangan Lex Mercatoria. Lebih jauh, konvensi-konvensi multilateral telah mengangkat prinsip-prinsip "party autonomy" pada level hukum internasional.

\section{Daftar Pustaka}

Castel, J.G., The Canadian Law and Practice of. International Trade with Particular Emphasison ExportandImport of Goods and Services, Emond Montgomery Publications Limited, Toronto, 1991.

Conant, M., "The Commerce Clause, the Supremacy Clause and the Law Merchant : Swift v. Tyson and the Unity of Commercial Law", Journal of Maritime Law and Commerce, Vol. 15 No. 2, 1984.

Cremades, B.M. dan S.L.Plehn, "The New Lex Mercatoria and the Harmonization of the Laws of International Commerctal Transactions", Boston University International Law Journal, Vol. 2, 1994.

Echols, J.M. dan H. Shadily, Kamus Inggris Indonesia, PT. Gramedia Pustaka Utama; Jakarta, 1993.

Glenn, H.P., Harmonization of Private Law Rules Berween Civil and Common Law Jurisdictions, Makalah disampaikan pada "The XIIIth International Congress of Comparative Law"; Montreal, Agustus 1990.

13). Lihat M. Conant, "The Commerce Clause, the Supremacy Clause and the Law Merchant :Swift v. Tyson and the Unity of Commercial Law", Journal of Maritime Law and Commerce, vol 15 No. 2, 184, hal. 153-178; M. Hunter, 'Lex Mercatoria : DeutscheSchachtbau-und Tiefbohgersellschaft mbH v. R'As Al khaimah national Oil Co, Lloyd's Maritime and Commercial law Quarterly, vol 3, 1987, hal 277 - 280. 
Hunter, M., "Lex Mercatoria : Deutsche Schachtbau-und Tiefbohrgesellsechaft mbH v. R' As Al Khaimah National Oil Co, Lloyd's Maritime and Commercial Law Quarterly, Vol. 3, 1987.

Kusumaatmadja, Mochtar, "Harmonisasi

Hukum Negara-negara ASEAN dalam Rangka AFTA dan Harmonisasi Hukum Perdagangan Internasional pada
Umumnya", Journal Hukum, No. 1 Vol. $1,1994$.

Lando, Ole, "The Lex Mercatoria in International Commercial Arbitration", International and Comparative Law Quarterrly, Vol. 34, 1985.

Mustill, T.R.H.L.J., "The New Lex Mercatoria : The First Twenty-five Years", Arbitration International.

Stoecker, "The' Lex Mercatoria : To What Ex- 